DOI: $10.20472 / B M .2015 .3 .2 .005$

\title{
BENEFITS OF DUAL-CAREER SUPPORT FOR EXPATRIATE SPOUSES
}

\section{KATHARINA SILBERBAUER}

\begin{abstract}
:
The purpose of the paper is to explore the benefits of on-assignment dual-career support for expatriate spouses. The article is based on survey data collected from a large organization in the oil and gas industry. The author argues in favor of the hypothesis that dual-career support is beneficial for trailing spouses. Cultural and occupational support is perceived as most favorable. The main limitation is that the study's focus was solely on the preferences of spouses of employees working in one company in the oil and gas industry. The findings must therefore be understood in the context of this environment. Based on the research results, HR practitioners are advised to set up or adjust their international assignment guidelines to fit the needs of dual-career couples.
\end{abstract}

\section{Keywords:}

international human resource management, international assignments, dual-career support, expatriate, benefits, trailing spouse;

JEL Classification: F01, F23, M52

\section{Authors:}

KATHARINA SILBERBAUER, University of Latvia, Latvia, Email: katharina.silberbauer@gmail.com

\section{Citation:}

KATHARINA SILBERBAUER (2015). Benefits of Dual-Career Support for Expatriate Spouses.

International Journal of Business and Management, Vol. III(2), pp. 66-84., 10.20472/BM.2015.3.2.005 


\section{Introduction}

Several studies (e.g. Krause-Nicolai 2005) have shown that the occupation of the expatriate's partner plays a major role when it comes to the success of an international assignment. Consequently, companies have tried to implement different kinds of measures to prevent the failure of assignments due to dual-career issues. However, the outcome of these policies remains unclear. Few studies have considered the expatriate adjustment process from the spouse's point of view. In light of increasing numbers of dual-career couples, this is a research gap that still needs to be covered (Andreason 2008).

There are several reasons why a company should consider expatriate spouses in their assignment policies, one being the improved performance of expatriate managers (Harvey 1998, p. 324). In cases where the situation at home reduces the general wellbeing of an employee, the productivity at work is usually negatively affected. Furthermore, it is in a company's interest to consider expatriate spouses before sending employees abroad for the following reasons (Black and Stephens 1989, p. 541):

- the opinion of the spouse about accepting the international assignment is related to spouse adjustment,

- spouse adjustment is positively related to expatriate adjustment and expatriate intentions to stay or leave and,

- premature returns are quite costly.

International assignments are in any case expensive but poor performance or early returns are even more costly. It is difficult to quantify the actual costs that go beyond the mere transfer and salary costs. However, a study from the late 1980s estimated that direct costs of expatriate failure for American companies amounted to some two billion USD a year, which is likely to have increased since then (Jack, Stage 2005, p. 49). Practitioners report that the average cost to a company in the first year of an international assignment is more than USD 250,000. The cost of a failed expat contract is estimated at about three times the employee's annual package (Vermeulen 2011). Another study gives an estimation of assignment costs ranging between three and six times compared to local employment costs, which is substantial (Ernst \& Young 2012, p. 20).

In case of premature returns to the home country, this is likely to result in a considerable loss of return on investment for the company and also to dissatisfaction among the expatriates. In a survey conducted in $2011,85 \%$ mentioned that less than $10 \%$ of their assignees return home earlier than planned. Yet, 15\% indicated that more than 10\% return prematurely, which is expensive and may harm the business (Ernst \& Young 2012, p. 17). Practitioners estimate that roughly $40 \%$ of all expat contracts fail, including expats returning home and also those who have a low level of productivity (Vermeulen 2011).

At the same time, work structures are becoming more international and complex. Companies increasingly cross borders and want to enter new markets. Nowadays, even small and medium-sized companies have expatriates in their workforce. This means that considerably more companies are faced with the challenges of sending people abroad as a result of globalization. In order to be successful in a foreign country, it is necessary to 
generate specific know-how (which must be used appropriately). In light of globalization, it is essential for companies to develop spouse-friendly HR (human resources) policies to maintain and improve competitive advantage (Konopaske et al., 2005, p. 423). Enabled by the internet, business processes are getting more and more interconnected, and system structures are becoming more flexible. These changes lead to a lower degree of standardization and a more complex environment. This means organizations need to learn about social, legal, economic, political, cultural and ethical changes (Epstein 2003, pp. 70-71). Despite recent economic downturns, companies have not stopped entering new markets, and continue to strive to be global players. With this in mind, corporate talent management programs that enable the development of global managers are essential. There is an increasing need for managers for international assignments to support their professional advancement (Bello, Tinder 2009, p. 38).

\section{Definition and Characteristics of Trailing Spouses}

A so-called trailing partner/spouse is "a person, traditionally a woman, who sacrifices her own job or career to allow her partner to take a new job in a different location. The phenomenon of the trailing wife is perhaps less common owing to the spread of dualearner families, in which both partners develop a career" (Heery, Noon 2008). The author of this paper uses the term 'trailing spouse' to neutrally describe accompanying partners without any further connotation, e.g. in regard to gender or status.

The author would like to take a closer look at the educational background of trailing spouses. Crispell and Du (1995, p. 32) have found out that education levels are not only relevant for a couple's income. The education levels also influence how the couples talk, use media and make consumer decisions. For example, they showed that collegeeducated couples are more likely to state that large purchases are joint decisions.

Crispell and Du (1995, p. 32-33) have shown in their study in the U.S. that education makes a difference in regard to the employment status of couples. The population of single earners has dropped steadily from $39 \%$ in 1980 to $28 \%$ in 1994 . For $18 \%$ of the couples, both partners were without a job. Couples without two salaries can be found in all educational cohorts, however there are some peaks. Examples of single earning couples are parents with small children or couples with one partner momentarily without a job. Some are single earners or permanently without a job, e.g. retirees and older couples.

The educational background differs within relationships. In $24 \%$ of cases the husbands are better educated and in $21 \%$ the wives are better educated. Education is positively related to earnings, at the same time well-educated couples are also more likely to work in general. Among couples without high school diplomas, just $24 \%$ are dual-earner households and $42 \%$ are without a salary (the main reason for this being their age or because they are retired). 55\% of couples with two high school degrees have two salaries. $70 \%$ of couples with university degrees are dual-earners (Crispell, Du 1995, p. 32-33). Although these data are from the U.S. it is likely that the situation is similar in other industrialized countries. The positive correlation of high educational levels with higher income can most likely be found in many countries. Also, the finding that there is a high proportion of dual-earner households among university graduates seems to be generally applicable. 
Another question is that of who is making decisions in a relationship. Evidence suggests that this is also related to the educational background of a couple. With higher education, a couple's decisions are more likely to be made together. Only $46 \%$ of wives who did not finish high school say they are equal partners in the couples' financial decision-making, compared with two-thirds or more of other wives (Crispell, Du 1995, p. 34).

Apart from the educational levels, it might also be helpful to take a look at the careerorientation of accompanying partners, as studied by Stephens and Black (1991). They refer to earlier publications where they mention that spouses with comparatively high earnings or high-status professions have significant influence on family relocation (Stephens, Black 1991 p. 418). It is not surprising that career-oriented spouses experience unemployment or career interruptions as more severe than spouses without major career expectations. The authors define career-oriented spouses as individuals with higher incomes who are in professional or managerial jobs and put a lot of effort into finding work - this ensures that they would lose more in a case of unemployment (Stephens, Black 1991, p. 419).

Stephens and Black (1991, pp. 422-423) made four major findings in regard to the career orientation of trailing spouses:

1. Spouses with earnings above the median prior to the transfer are more likely to find work after the transfer than their lower earning counterparts (even though a majority of spouses could not find work abroad).

2. Couples in which the spouse worked before the transfer but not upon return do not report a lower standard of living than couples in which the spouse worked both before and after the transfer. In general, the expatriate remuneration compensates for the loss of the second income. Career-oriented spouses are not likely to experience significant job interruption, but should the situation arise, they face the strongest negative impact.

3. No significant differences were found between the adjustment levels of expatriate managers whose spouses only worked before the transfer, and managers whose spouses worked before and after the transfer.

4. Expatriates whose spouses only worked before the transfer did not report a higher risk of premature return than managers whose spouses worked both before and after the international assignment. However, the spousal home salary negatively correlates with the expatriate manager's retention, meaning that the higher the spouse's income in the home country, the lower the commitment of the expatriate to stay in the assignment.

Well-paid spouses are more likely to find a job upon repatriation than others, and the international experiences might even compensate for the negative effects of job interruptions faced by non-career-oriented partners (Stephens, Black 1991, p. 426). The findings described above suggest that the characteristics of trailing spouses are very diverse, and that there are many influencing factors on an individual level. This makes it difficult for research in this area to formulate generalized statements that are applicable for the entire population of expatriate spouses.

Pursuing the thought that the number of dual-career couples is increasing, it is also worthwhile to reconsider the influence the partner has on one's career. A study of Israeli 
managers (Grossbard-Shechtman et al. 1994, p. 165) showed that about two-thirds of men appreciated that their spouses helped them with the progression of their career. It is therefore not surprising to see that married men on average earned more than unmarried ones. A majority of women also claimed that they were supported by their husbands. It seems that husbands are more likely to support when it is most needed and productive (e.g. with small children). The survey results also show that young women get more support. This could be for one of three reasons: First, the couple is confronted with younger children; second, the woman still has a long career ahead of her; or third, the couple has less traditional values. In general, the spouse's willingness to support the partner's career also depends on the probability of divorce, and the profitability of the investment and expected return.

Overall, the results show that both men and women acknowledge the spousal support for the promotion of their careers. This could mean that high income individuals are not more likely to get married, but rather that married employees are benefitting from spousal resources resulting in higher income levels (Grossbard-Shechtman et al. 1994, p. 165). Partners may also have an influential role during international assignments. The trailing spouses are typically eager to spend their free time and resources on social networking and strategic alliances in order to improve their husband's standing within the organization and enhance career opportunities (Lauring, Selmer 2010, p. 66). This means the expatriate employers could make use of these assets by offering training to the spouses, and at the same time easing spousal dissatisfaction (Lauring, Selmer 2010, p. $67)$.

It seems that the influence of international assignments on career perspectives is also influenced by the duration of an assignment. Thornton and Thornton (1995, p. 61) observed that when it comes to assignments that do not exceed a six month duration, expatriate spouses are not confronted with career issues. For this period the assignment is considered to be a long vacation, and the spouses will return to their home jobs. This means that if companies think about offering short-term assignments, the difficulties for those dual-career couples could be reduced.

\section{Work-Family Conflict}

The dominant approach to research in the area of work and family is the work-family conflict. This proposes that individuals have a limited energy level, which is affected by taking on multiple roles (Barnett, Gareis 2006). Considering higher employment rates of mothers and an increase in single-parent households, it makes balancing conflicts between family and work responsibilities even more demanding (Ruhm 2004, p. 2).

Allard et al. (2011, p. 144) mention that there are two dimensions of work-family conflict: work-to-family conflict (work interferes with family) and family-to-work conflict (family interferes with work). Apart from the two different dimensions work-family and family-work conflict, there are three different types of work-family conflict: time-, strain- and behaviorbased conflict (Hargis et al. 2011, p. 388). An example of a time-based conflict is a situation when more time is spent in one role, which is then missing in the other role. A strain-based work-family conflict refers to the case when the person experiences stress or tension in one role, which negatively reflects on the other role as well. Behavior-based conflicts arise when the two roles ask for different behavior patterns. 
Hein (2005, pp. 3-9) identifies different origins of the work-family conflict. She mentions the separation of home and workplace, the increasing labor force participation of women, the declining availability of family assistance, the increasing care needs of the elderly, pressure of work and long working hours, longer travel time to and from the office, and stress caused by HIV/AIDS. Whereas the background of the work-family conflict falls into the category of societal determinants for the situation of dual-career couples, the consequences are experienced by individuals.

The most important factors influencing the work-family conflict are (Hargis et al. 2011, pp. 389-391):

- job and family stressors,

- levels of social support,

- levels of job and family involvement,

- number of working hours,

- number and ages of children,

- personality/perception of situations.

Out of these factors, negative perceptions and job stressors are most influential (Hargis et al. 2011, p. 401). Hargis et al. (2011, p. 386) summarize previous studies by explaining the most important outcomes of work-family conflict, namely job and life satisfaction, psychological distress, chronic health problems, job performance and absenteeism, turnover intentions and voluntary turnover.

Hein (2005, p. 24) points out that only a few industries have considered family support in the past (e.g. only in remote locations such as plantations or mines). In contrast, other industries have typically separated work and family by not perceiving family matters as their responsibilities. Rather, industries believe that family is the sole responsibility of the employee, who has to make sure that there is no interference with work.

Looking at multi-national corporations in our society today, most of them are likely to have bureaucratic structures. As this organization is characterized by an emphasis on technical expertise and a system of hierarchical surveillance, evaluation, and direction (Ouchi 1980 , p. 134), it is not surprising that companies traditionally do not interfere with the family situation of their employees. Hein (2005, p. 25) explains that the tradition that companies do not feel responsible for families is based on the male breadwinner model where the employee could not risk losing his job because the family was dependent on one income. Today's two-income couples present a new situation that puts the family on the company's agenda. Companies should take over a more proactive role in supporting their staff to decrease work-family conflict (Powell, Greenhaus 2010, p. 528).

Study results suggest that there is a difference between men and women in regard to work-to-family positive spillover. Female employees showed higher levels of positive spillover than men, while experiencing a similar work-family conflict (Powell, Greenhaus 2010 , p. 526). Independent of gender, employees show lower potential for conflicts but also for positive spillover if they separate work and family more strictly (Powell, Greenhaus 2010, p. 525). This means that if one tries to keep the spheres apart, this will have both negative and positive effects. In the past, organizations were focusing on 'face 
time' and '24/7' accessibility which is now being questioned because of the increasing work-family conflict. Accordingly, companies could offer training in how to transfer the values, skills, and behaviors acquired at work to the family sphere (Powell, Greenhaus 2010, p. 528).

Data from an empirical study in Canada shows a reduction of job satisfaction and organizational commitment between the years 1991 and 2001 (Duxbury, Higgins 2003, p. 40). This went along with an increase in work-life conflict, which leads to the conclusion that business practices such as downsizing, re-engineering/re-structuring, long working hours or pay freezes have negative consequences on employee perceptions of the job and the employer (Duxbury, Higgins 2003, p. 40).

Organizations and individuals can show different reactions to these circumstances. Barnett (1999, p. 146-147) describes the situation when family matters are not considered at work with the separate-spheres model. According to this model, the spheres have strict boundaries: each sphere has its own demands, which leads to a consistent struggle. Women are in charge of handling both spheres, and if they cannot separate family matters from work it means there are inadequate boundaries and inappropriate priorities. The author argues that this behavioral pattern still heavily influences corporate policies today.

Following the societal developments, Barnett created the new overlapping-spheres model (1999, p. 149). According to this new model, there is interdependence between work and life as well as a shift from the single focus on problems to an acknowledgement of the positive outcome of operating in two spheres at the same time. In addition, boundaries are less clear with less emphasis on interface issues. Finally, Barnett (1999, p. 151) proposes the work-life integration model as the ultimate goal: where family demands are in harmony with both workplaces, with the underlying assumption that a good job benefits the employee and the spouse (see figure below).

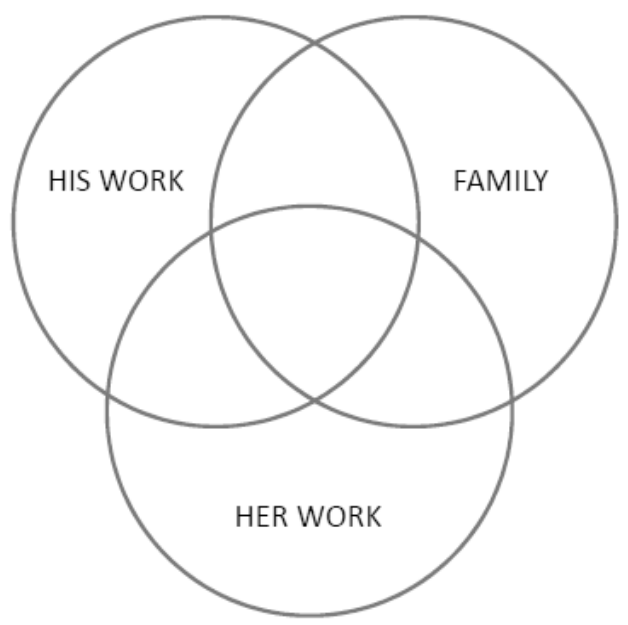

Figure 1: The work-life integration model

Source: Barnett 1999, p. 151

High levels of role overload are typical for employees of large companies. $58 \%$ of the questioned employees stated that they had high levels of role overload, while an additional $30 \%$ showing moderate levels of role overload. This is opposed to $12 \%$ with 
low levels of overload (Duxbury, Higgins 2003, p. xii). It also seems that working long hours has become significantly more common over time. The below table illustrates the increase for employees working 50 weekly hours or more and the decrease for staff working less than full-time which has been reported for all job groups and sectors (Duxbury, Higgins 2003, p. xii).

Table 1: Working time in Canada (1991 vs. 2001)

\begin{tabular}{|l|l|l|}
\hline Working time & 1991 & 2001 \\
\hline 50 or more hours & $10 \%$ & $25 \%$ \\
\hline between 35 and 39 hours & $48 \%$ & $27 \%$ \\
\hline
\end{tabular}

Source: author's own table based on Duxbury, Higgins 2003, p. xii

Evidence suggests that work-family conflict is a major problem for Canadian employees in large companies where $25 \%$ mention that work responsibilities interfere with responsibilities at home, and almost $40 \%$ report moderate interferences (Duxbury, Higgins 2003, p. xii). When it comes to family-work conflict, evidence from Canada suggests that this is uncommon: only $10 \%$ claim high levels of family-work conflict (Duxbury, Higgins 2003, p. xii).

When it comes to an international assignment, the work-family conflict can be even worse. The roles and responsibilities of the family members may change, for example due to work permit restrictions, which could turn a dual-career couple into a singlebreadwinner household (Harvey, Buckley 1998, p. 101).

\section{Dual-Career Support}

Companies have developed different kinds of support measures to be offered to their employees in order to overcome the negative consequences of dual-career relationships. The ways in which companies offer organizational support differ widely. Saxena and Bhatnagar (2009, p. 84) note that corporate policies are still mainly built around the outdated belief that the (male) employees have a support system at home and they can exclusively focus on their professional lives. Nevertheless, companies have identified several family-friendly policies such as part-time work, flexible schedules, job-sharing, alternative work locations, workplace nursery, resource and referral programs and support groups (e.g. Hanis 2005, pp. 24-29). However, many organizations still restrict family-friendly programs to women-friendly childcare support (Hein 2005, p. 62). Companies only now realize that work-family programs need to have a broader perspective. Even though companies have started to introduce such measures, they have not assessed and compared costs that would result from adopting family-friendly arrangements (Hein, 2005, p. 25). Research data implies that smaller companies are less likely to offer family-friendly benefits than large firms (Ruhm, 2004, p. 4). Hein (2005, p. 28) adds that family-friendly programs are most popular in high-skilled industries and sectors where the costs of losing and replacing an employee are high and the benefits of family-friendly practices are easier to quantify.

Dual-career support covers company-sponsored support that is aimed at enhancing the mobility of dual-career couples, especially through supporting the expatriate spouse's professional career. Dowling and Welch (2004) point out that there are several methods of supporting the spouse's career: 
- inter-company networking (the employer supports the spouse to find a job in the same location but at a different company),

- job hunting assistance (e.g. employment agency fees, career counseling, work permit assistance),

- intra-company employment (the spouse is offered a job in the same branch office),

- on-assignment career support (e.g. lump sum payments for education expenses, professional association fees, seminar attendance, language training, employment agency fees, career development activities).

This shows that dual-career support is not necessarily bound to paid employment in the host country. For various reasons (such as work permit restrictions, language barriers or non-acceptance of formal education) actual work might not be possible. Therefore, measures that support the spouses' career not immediately but only in the long run are included in dual-career support policies.

Konopaske et al. (2005, p. 420) mention the same career support methods, but added the introduction to decision makers in other multinational companies in the host country as a possible form of overseas career support for spouses. They also highlight the importance of intercultural training and introducing spouses to repatriated spouses of former expatriates. Expatriates often wish to receive a reimbursement for spouse education costs and help with arranging work permits for the partner (Suutari, Tornikoski 2001 , p. 400). Bauer and Taylor (2001, p. 137) advise companies to offer language courses and intercultural training for spouses and to support them with building social networks, e.g. by arranging social events, providing cultural counsellors and prerelocation training which will leader to more successful assignments.

Suutari and Tornikoski (2001, p. 398) report spouse-related disadvantages such as the loss of salary and pension contributions of the spouse during the international assignments. The expatriates also asked for a compensation for the second income because the household income was lower during the assignment. Paid employment for accompanying spouses would usually improve the dual-career dilemma, however, few companies provide spouse employment opportunities (Thornton and Thornton 1995, p. $60)$. It is also important to say that the financial position of a dual-career couple makes a difference when it comes to work-family interference. Wealthier couples could afford to hire some help, which reduces household responsibilities (Stringer-Moore 1981, p. 395).

There are different answers to the above-mentioned problems. Harvey (1998, p. 325) summarizes spouse support from different assignment policies: job-related assistance (counselling and preparation for overseas career opportunities, job support within a multinational corporation or with international counterparts, professional international placement assistance, support for advanced education opportunities, creating tasks for spouses) and operational support (realistic 'preview' of international relocation/Look \& See trip, flexible housing solutions/commuting options, short-term assignments) and other occasional support. Even if family-friendly policies exist, availability is still subject to supervisory discretion, which means they might not be equally accessible (Crompton et al. 2007, p. 9). 
There are certainly many different ways to support dual-career couples during international assignments. According to the Brookfield Survey Report (2010), companies most frequently assist the expatriate spouse with language training (85\%), educational assistance (38\%) and company-sponsored work permits (34\%).

Punnett (1997, pp. 250-251) highlights that the spouse should be considered in the entire assignment life cycle, meaning pre-assignment, early assignment, late assignment and post assignment. Pre-assignment measures typically include Look \& See trips, language training and intercultural training. The early assignment phase is usually more informal with support groups consisting of local managers and spouses. If the expatriates survive the culture shock, they enter the late assignment stage where the most important thing is to keep in touch with the home company/country. The post-assignment stage usually also contains a culture shock and difficulties with adjustment.

Harvey (1998, p. 321) argues that the level and quality of support for the dual-career couple will be influenced by the family background (quality of the marriage), the social network in the new environment, the similarity between the home and host support systems and the individual characteristics of the couple (willingness to seek and provide support). A survey among 31,571 Canadian employees showed that $75 \%$ of the respondents are currently married or living in a relationship and $69 \%$ are part of a dualincome family (Duxbury, Higgins 2003, p. xi). Apart from the fact that there is a rising number of dual-career couples, there are also other occurrences gaining importance. There is not only a change from single- to dual-earners households, there are additionally plenty of new structures such as single-parent families, stepfamilies, blended families and gay and lesbian families that question the conventional thinking about work and family (Barnett 1999, p. 148).

Some companies have introduced dual-career policies as highlighted above. Still, these should be reviewed in regard to the individual needs of the couples. Harvey (1998, p. 321) mentions the following aspects that need to be considered in terms of support infrastructure:

- emotional needs of the dual-career couple;

- instrumental needs, i.e. time, resources and skills provided by the company to provide assistance in adjustment to dual-career couples;

- infrastructural support on the provision of facts, opinions, and advice while on the expatriation assignment and

- appraisal support which supplies the dual-career couple with feedback on performance as well as adjustment overseas (House, 1981; Granrose et al, 1992).

Apart from the above-mentioned needs, considering the following three different groups of spouses is also recommended because each needs different treatment (Punnett 1997, pp. 247-248):

- female spouses who do not expect to work abroad ('traditional expatriate spouses'): major concern is cultural adjustment;

- female spouses who do expect to work abroad: major concern is job/educational opportunities; 
- male spouses who predominantly expect to work abroad: major concern is job opportunities and emotional support;

Several studies have shown that the professional situation of expatriate spouses is heavily affected by international assignments. The Brookfield Survey Report (2010), for example, shows that out of the interviewed spouses $50 \%$ were employed prior to the foreign assignment. Not surprisingly, only a small number - namely $9 \%$ - were employed both before and during the assignment. Even if this figure might not be the same for every position and location - for other figures see, for example, the Permits Foundation Survey 2008 - it still shows that the employment rates considerably decrease for trailing spouses. This is closely related to the career-orientation of the spouses. In case the partners are highly career-oriented before the international assignment, they are also more likely to find a job during and after the assignment. One can assume that careerorientation is linked to the level of education, which supports the proposed hypothesis that spouses with higher levels of education are more likely to claim dual-career support.

As an example of inappropriate benefit schemes Adler (2002, p. 754) mentions companies that offer complimentary club memberships for elite social and sports organizations but forget about providing commuting options, which would be especially important for women in dual-career partnerships. This shows that companies do not differentiate who is sent abroad but offer standardized schemes that might not fit for everybody.

Some companies could argue that including the spouse in the assignment process is discriminating against other employees. Brummelhuis and van der Lippe (2010, p. 187) note that single expatriates might have a feeling of envy or exclusion when they are confronted with a family-supportive culture. However, if the policies are transparent and clear for everybody and the spouses are willing to participate, this problem can be solved (Punnett 1997, p. 254). Companies who think about offering the accompanying partner a job in the company should also think about possible risks. Considering that the spouse does not have to go through a demanding recruiting process, other candidates could feel discriminated against and might even sue the company (Stringer-Moore 1981, p. 394). Nevertheless, companies could mention in their job ads that they encourage couples for applications, which could attract candidates who might not have applied otherwise (Stringer-Moore 1981, p. 395). Overall there are plenty of possibilities to support dualcareer couples. Companies should review which ones best fit their employees and corporate strategies.

There are several benefits of dual-career support for the expatriate spouses. They are directly affected by most of the policies and can benefit from them. Of course, a prerequisite is that they are made aware of the company-provided support systems. The measures can either help them on an emotional level, like improved adjustment to the new culture, on a professional level, e.g. cost coverage for educational expenses, on an operational level, e.g. paid child care facilities, or in financial terms, for example a compensation for lost income.

At the same time, the policies usually do not directly involve the expatriate. Nevertheless, there are spillover effects in relationships. Van der Zee et al. (2005, p. 239) identify spillover effects in terms of subjective well-being meaning that emotional stress is transferred from one partner to the other. This means if the partner feels bad, the 
expatriate will also suffer. The main reasons companies should consider on-assignment support are spillover effects from the spouse to the expatriate (leading to decreased productivity) and low employee mobility if the company does not care about the spouses. The Brookfield Survey Report (2010) showed that the main reason for the refusal of an assignment were family concerns and spouse/partner's career. At the same time, the most important factor in terms of assignment failure was spouse dissatisfaction.

Even though literature supports the idea of dual-career programs, reality seems to lag behind (Anderson 2001, p. 114). Krause-Nicolai (2005) found in her study that preparation, on-assignment support and reintegration of dual-career couples are insufficient in German companies. Her empirical results show that the solutions for the expatriate couples were typically not employer-initiated but based on private commitment. She argues that companies could achieve considerably higher satisfaction among dualcareer couples by providing some custom-tailored support. Higher satisfaction also goes along with less stress and increased productivity. Even though the possibility of work for the spouse in the host country is an important factor, Krause-Nicolai (2005, p. 225) mentions that this does not determine the decision for or against an international assignment. Still, many dual-career couples appreciate career counselling.

Offering dual-career support definitely creates an additional financial burden for companies. However, literature suggests that the actual costs are insignificant compared to the achieved savings (e.g. Bello, Tinder 2009, p. 39):

- Without dual-career support resistance from the family will make a move more unlikely.

- Dissatisfaction at home leads to reduced productivity at the workplace.

- Higher retention rates reduce the costs of an assignment.

- Family-friendly policies bring a competitive advantage (meaning that a company might be able to attract candidates who would otherwise have not been available.

When looking at the benefits provided through international assignment policies, it is important to note that expenses for dual-career support are marginal compared to the total costs of an assignment (typically less than 1\%), while at the same time they could make a considerable difference for the overall outcome of an assignment (Bello, Tinder 2009 , p. 39). Nevertheless, it might be difficult for companies to measure the benefits and costs related to the provided support.

If no support is provided by the expatriate employer, the expatriates themselves have to put effort into the situation of their spouses which will have negative effects on their organizational loyalty, job commitment and mobility (Kupka, Cathro 2007, p. 964). It is clear that if the employees have to spend time on the career situation of their spouses, less time is spent on their own work which is not in the interest of the employer.

Even though it is clear that it makes sense for employers to spend resources on dualcareer support, the author would like to explore in which way the support will be beneficial for expatriate spouses. 


\section{Methodology}

The literature review is based on journal articles and books, complemented by online publications freely accessible in the internet. Apart from the literature review, the author conducted an online survey for expatriate spouses. The empirical data are analyzed through descriptive statistics, factor analysis and analysis of variance.

An email was sent to all 422 active expatriates of one international company who had declared to be married or in a relationship (out of those 48 were women). The expatriates were asked to forward the email to their spouses so they could participate in the survey. In total, 108 expatriate spouses participated in the study. The data was collected via an online self-completion questionnaire using professional survey software. The web-based delivery of the survey was considered appropriate for the people in the sample, as they most probably use the internet to stay in touch with their friends and families in the home country and are therefore computer literate. The survey was available in English and German in order to reduce errors linked to language difficulties.

The respondents had 24 different citizenships and were sent to 14 different host countries. Unsurprisingly, there were more female than male spouses $(86.36 \%$ vs. $13.64 \%)$. Most of the respondents were university graduates $(73.86 \%)$. The majority of the spouses $(52.27 \%)$ were in the age category of $30-40$ years. The age factor is an interesting way to see the life-cycle stage the partners are currently in. There are two stages that are said to face most work-family conflict: parents who have young children at home and are in the 'full-nest' stage of the life-cycle and those between child care and care for the elderly, also called the sandwich generation (Duxbury, Higgins 2002, p. 37). The survey data suggests that the majority of the partners are in the age group that has a high risk for work-life conflict. The majority had two children.

\section{$6 \quad$ Empirical Findings}

The underlying survey question was "In which way would the support be beneficial for you?". A factor analysis results in four well-interpretable factors. The first factor can be interpreted as 'Emotional benefits due to work', the reliability is Cronbach's $\alpha=0.86$. The second factor is interpreted as 'Occupational benefits' and also has a good reliability (Cronbach's $\alpha=0.82$ ). The third factor is interpreted as 'Emotional benefits due to unpaid activities' with a reliability of Cronbach's $\alpha=0.74$. The fourth factor can be described as 'Cultural benefits' with a reliability of 0.75 . 
Table 2: Factor analysis of the benefits

\begin{tabular}{|l|l|l|l|l|}
\hline & $\begin{array}{l}\text { Comp } \\
\mathbf{1}\end{array}$ & $\begin{array}{l}\text { Comp } \\
\mathbf{2}\end{array}$ & $\begin{array}{l}\text { Comp } \\
\mathbf{3}\end{array}$ & $\begin{array}{l}\text { Comp } \\
\mathbf{4}\end{array}$ \\
\hline Emotional benefits due to work & & & & \\
\hline $\begin{array}{l}\text { I feel more satisfied if I have my own job. - } \\
\text { Strongly agree }\end{array}$ & 0.87 & & & \\
\hline $\begin{array}{l}\text { I feel more relaxed around my family if I } \\
\text { have my own job. - Strongly agree }\end{array}$ & 0.85 & & & \\
\hline $\begin{array}{l}\text { I have more self-respect if I have my own } \\
\text { job. - Strongly agree }\end{array}$ & 0.71 & & & \\
\hline $\begin{array}{l}\text { I feel less isolated if I have my own job. - } \\
\text { Strongly agree }\end{array}$ & 0.66 & & & \\
\hline $\begin{array}{l}\text { It is financially comforting that I can } \\
\text { contribute my own part to the family } \\
\text { income. - Strongly agree }\end{array}$ & 0.54 & & & \\
\hline Occupational benefits & & & & \\
\hline $\begin{array}{l}\text { The further education during the } \\
\text { assignment will be an asset for my future } \\
\text { career. - Strongly agree }\end{array}$ & & 0.82 & 0.20 & \\
\hline $\begin{array}{l}\text { It feels good to have time to participate in } \\
\text { further education. - Strongly agree }\end{array}$ & & 0.76 & 0.12 & \\
\hline $\begin{array}{l}\text { I feel satisfied when I can develop my } \\
\text { career while abroad. - Strongly agree }\end{array}$ & & 0.72 & 0.21 & \\
\hline $\begin{array}{l}\text { The work experience in the host country } \\
\text { will be an asset for my future career. - } \\
\text { Strongly agree }\end{array}$ & & 0.58 & 0.09 & \\
\hline $\begin{array}{l}\text { Emotional benefits due to unpaid } \\
\text { activities }\end{array}$ & & & & \\
\hline $\begin{array}{l}\text { I feel more satisfied if I am engaged in } \\
\text { volunteer work than only staying at } \\
\text { home. - Strongly agree }\end{array}$ & & & 0.85 & \\
\hline $\begin{array}{l}\text { I have more self-respect if I am engaged } \\
\text { in volunteer work. - Strongly agree }\end{array}$ & & & 0.83 & \\
\hline $\begin{array}{l}\text { I feel more relaxed around my family if I } \\
\text { have my own activities. - Strongly agree }\end{array}$ & & & 0.74 & \\
\hline $\begin{array}{l}\text { My partner's employer finances training } \\
\text { courses / seminars etc. which I could or } \\
\text { would not have afforded otherwise. - }\end{array}$ & & & 0.51 & \\
\hline
\end{tabular}




\begin{tabular}{|l|l|l|l|l|}
\hline & $\begin{array}{l}\text { Comp } \\
\mathbf{1}\end{array}$ & $\begin{array}{l}\text { Comp } \\
\mathbf{2}\end{array}$ & $\begin{array}{l}\text { Comp } \\
\mathbf{3}\end{array}$ & $\begin{array}{l}\text { Comp } \\
\mathbf{4}\end{array}$ \\
\hline Strongly agree & & & & \\
\hline Cultural benefits & & & & \\
\hline $\begin{array}{l}\text { I feel more comfortable when I am aware } \\
\text { of intercultural differences. - Strongly } \\
\text { agree }\end{array}$ & & & & 0.89 \\
\hline $\begin{array}{l}\text { I feel more comfortable when I know the } \\
\text { local language. - Strongly agree }\end{array}$ & & & & 0.81 \\
\hline
\end{tabular}

Source: author's own table

Looking at the average values, it is highest for 'Cultural benefits' $(M=4.51, S D=0.63)$. 'Occupational benefits' have an average value of $M=4.52(S D=0.60)$. The average value for the index 'Emotional benefits due to work' is $M=4.20(S D=0.81)$. The lowest perceived benefit is 'Emotional benefits due to unpaid activities' $(M=3.76$; $S D=$ 0.74 ). The four averages are significantly different (analysis of variance for repeated measures: $F(3 ; 213)=29.411, p<0.001)$. Post-hoc Bonferroni tests demonstrate that 'Occupational benefits' and 'Cultural benefits' differ from all the others $(p<0.019)$. These two indices thus have the highest agreement, 'Emotional benefits due to unpaid activities' get the lowest agreement.

Table 3: Descriptive statistics for benefits

\begin{tabular}{|l|c|c|}
\hline & M & SD \\
\hline Emotional benefits due to work & 4.20 & 0.81 \\
\hline Occupational benefits & 4.42 & 0.60 \\
\hline $\begin{array}{l}\text { Emotional benefits due to unpaid } \\
\text { activities }\end{array}$ & 3.76 & 0.74 \\
\hline Cultural benefits & 4.51 & 0.63 \\
\hline
\end{tabular}

Source: author's own table

Subsequently, the author analyzes whether the meaning of the benefits is dependent on partner-specific variables. Therefore, a multivariate analysis of variance is used with the four indices as dependent variables. The independent variables are age, education, existence of children, partner's length of stay abroad, current residence, former stay abroad, jobs before stay abroad and current employment status.

There is no significant difference in the four indices regarding couples with or without children $(F(4,53)=1.408 ; p=0.244)$. The age has no statistically demonstrable impact on the evaluation of the benefits. There are also no differences among the age groups ( $F$ $(8 ; 134)=1.888 ; p=0.067)$. Also the education of the partner makes no significant difference $(F(8 ; 134)=1.135 ; p=0.344)$. The duration of the current assignment plays no role $(F(8 ; 134)=0.364 ; p=0.938)$. The same is the case for the current residence ( $F$ $(4 ; 67)=1.306 ; p=0.277)$ and their own stay abroad $(F(12 ; 156)=0.987 ; p=0.464)$. There is no statistically significant impact on the evaluation of the four indices. A 
significant difference exists, however, depending on whether the partner had a job before the relocation $(F(4 ; 52)=5.824 ; p=0.001)$.

Table 4: Descriptive statistics for the benefit indices, by employment status of the partner before stay abroad

\begin{tabular}{|l|c|c|c|c|}
\hline & \multicolumn{2}{|c|}{ Employed } & \multicolumn{2}{c|}{ Unemployed } \\
\hline & $\mathbf{M}$ & SD & $\mathbf{M}$ & SD \\
\hline $\begin{array}{l}\text { Emotional benefits due to } \\
\text { work }\end{array}$ & 4.41 & 0.69 & 3.57 & 0.86 \\
\hline Occupational benefits & 4.58 & 0.49 & 4.08 & 0.69 \\
\hline $\begin{array}{l}\text { Emotional benefits due to } \\
\text { unpaid activities }\end{array}$ & 3.73 & 0.78 & 3.76 & 0.60 \\
\hline Cultural benefits & 4.65 & 0.50 & 4.34 & 0.75 \\
\hline
\end{tabular}

Source: author's own table

Considering the univariate analysis of variance, there are significant differences for the indices 'Emotional benefits due to work' $(F(1 ; 55)=14.778 ; p<0.001)$ and 'Occupational benefits' $(F(1 ; 55)=9.609 ; p=0.003)$. Both benefits are much more important for partners who were employed before. There is no significant difference regarding the current employment of the partner $(F(4,67)=1.588 ; p=0.188)$.

\section{Discussion of Findings}

The hypothesis was that expatriate spouses benefit from dual-career support in multiple ways. The received answers give a clear indication that dual-career support leads to improved well-being and specifically cultural and occupational support is perceived as beneficial.

In general, it is difficult to compare the findings with previous research as the author is unaware of studies explicitly focusing on benefits of dual-career support. Even though dual-career support provides benefits for trailing spouses, it must not be forgotten that there are problems that cannot be solved by the company. This is, for example, the case if the host country labor market is restrictive and does not allow or need certain professions. Another issue is the difference in income levels between countries and a possible non-compatibility of pension systems. These issues should be placed on political agendas rather than on corporate schedules.

Consequently, the hypothesis that dual-career support is beneficial for the trailing spouse can be confirmed. The method proved to be appropriate because benefits for the expatriate spouse could be clearly identified. Future research could use these results in order to explore benefits for supplying industries such as relocation agencies, training providers or counsellors.

\section{Conclusion}

This study has helped to confirm that dual-career support is beneficial for expatriate spouses. Cultural and occupational support is perceived as most favorable. Overall, the study adds to existing studies by confirming that company-sponsored support is 
beneficial for spouses and therefore also for expatriate staff. However, the findings suggest that the dual-career will not have the same outcome for every couple, as the individual backgrounds are very different. Given these results, it is proposed to design international assignment guidelines in a way to appropriately include the spouses' needs and to raise awareness for dual-career concerns.

\section{References}

Adler, N.J. (2002), "Global managers: no longer men alone", The International Journal of Human Resource Management, Vol. 13 No. 5, pp. 743-760.

Allard, K., Haas, L. and Hwang, C.P. (2011), "Family-Supportive Organizational Culture and Fathers' Experiences of Work-family Conflict in Sweden", Gender, Work \& Organization, Vol. 18 No. 2, pp. 141-157.

Anderson, B.A. (2001), "When expatriation means 'Follow that woman!", Asia Pacific Journal of Human Resources, Vol. 39 No. 3, pp. 109-116.

Andreason, A.W. (2008), "Expatriate Adjustment of Spouses and Expatriate Managers: An Integrative Research Review", International Journal of Management, Vol. 25 No. 2, pp. 382-395.

Barnett, R.C. (1999), "A New Work-Life Model for the Twenty-First Century", The ANNALS of the American Academy of Political and Social Science, Vol. 526, pp. 143-158.

Barnett, R.C. and Gareis, K.C. (2006), "Role Theory Perspectives on Work and Family", in Pitt-Catsouphes, M., Kossek, E.E. and Sweet, S.A. (Eds.), The work and family handbook: Multi-disciplinary perspectives, methods, and approaches, Lawrence Erlbaum Associates, Mahwah, N.J.

Bauer, T.N. and Taylor, S. (2001), "When Managing Expatriate Adjustment. Don't Forget the Spouse", The Academy of Management Executive, Vol. 15 No. 4, pp. 135-137.

Bello, L. and Tinder, G. (2009), "Dual Career Implications on Workforce Mobility: The Evolution of the Relocating Spouse/Partner", Benefits \& Compensation Digest, Vol. 46 No. 9, pp. 36-39.

Black, J.S. and Stephens, G.K. (1989), "The Influence of the Spouse on American Expatriate Adjustment and Intent to Stay in Pacific Rim Overseas Assignments", Journal of Management, Vol. 15 No. 4, pp. 529-544.

Brookfield Global Relocation Services (2010), Global Relocation Trends: 2010 Survey Report.

Brummelhuis, L.L. ten and van der Lippe, T. (2010), "Effective work-life balance support for various household structures", Human Resource Management, Vol. 49 No. 2, pp. 173-193.

Crispell, D. and Du, F. (1995), "Dual-earner diversity.", American Demographics, Vol. 17 No. 7, pp. 32-39.

Crompton, R., Lewis, S. and Lyonette, C. (Eds.) (2007), Women, men, work and family in Europe, Palgrave Macmillan, Basingstoke [England]; New York.

Dowling, P.J., Welch, D.E. and Schuler, R.S. (2004-2005), International human resource management: Managing people in a multinational context, 4. edition, South-Western College, Cincinnati, Ohio.

Duxbury, L. and Higgins, C. (2003), Work-Life Conflict in Canada in the New Millennium: A Status Report.

Epstein, E.M. (2003), "How to Learn from the Environment about the Environment - A Prerequisite for Organizational Well-Being", Journal of General Management, Vol. 29 No. 1, pp. 68-80.

Ernst \& Young (2012), Global Mobility Effectiveness Survey 2012, Driving Business Success, US/Switzerland.

Granrose, C.S., Parasuraman, S. and Greenhaus, J.H. (1992), "A Proposed Model of Support Provided by Two-Earner Couples”, Human Relations, Vol. 45 No. 12, pp. 1367-1393.

Grossbard-Shechtman, S.A., Izraeli, D.N. and Neuman, S. (1994), "When Do Spouses Support a Career? A Human Capital Analysis of Israeli Managers and Their Spouses", Journal of Socio-Economics, Vol. 23 1-2, pp. 149-167. 
Hanis, A. (2005), "Is family and career a possible combination?", Diploma Thesis, Vienna University of Economics and Business, Vienna, 2005.

Hargis, M.B., Kotrba, L.M., Zhdanova, L. and Baltes, B.B. (2011), "What's Really Important? Examining the Relative Importance of Antecedents to Work-Family Conflict", Journal of Managerial Issues, XXIII No. 4, pp. 386-408.

Harvey, M. (1998), "Dual-career couples during international relocation: The trailing spouse", The International Journal of Human Resource Management, Vol. 9 No. 2, pp. 309-331.

Harvey, M.G. and Buckley, M.R. (1998), "The process for developing an international program for dualcareer couples", Human Resource Management Review, Vol. 8 No. 1, pp. 99-123.

Heery, E. and Noon, M. (2008), A Dictionary of human resource management, 2nd ed., Oxford University Press, Oxford.

Hein, C. (2005), Reconciling work and family responsibilities: Practical ideas from global experience, International Labour Office, Geneva.

House, J. (1981), Work, Stress, and Social Support, Addison-Wesley, Reading, MA.

Jack, D.W. and Stage, V.C. (2005), "Success Strategies for Expats", $T+D$, Vol. 59 No. 9, pp. 48-51.

Konopaske, R., Robie, C. and M. Ivancevich, J. (2005), "A preliminary model of spouse influence on managerial global assignment willingness", International Journal of Human Resource Management, Vol. 16 No. 3, pp. 405-426.

Krause-Nicolai, D. (2005), Dual Career Couples im internationalen Einsatz: Implikationen für das internationale Personalmanagement, P. Lang, Frankfurt am Main; New York.

Kupka, B. and Cathro, V. (2007), "Desperate housewives - social and professional isolation of German expatriated spouses", The International Journal of Human Resource Management, Vol. 18 No. 6, pp. 951-968.

Lauring, J. and Selmer, J. (2010), "The supportive expatriate spouse: An ethnographic study of spouse involvement in expatriate careers", International Business Review, Vol. 19 No. 1, pp. 59-69.

Ouchi, W.G. (1980), "Markets, bureaucracies, and clans", Administrative science quarterly, Vol. 25 No. 1, pp. 129-141.

Permits Foundation (2008), International Survey Summary Report: Expatriate spouses and partners employment, work permits and international mobility.

Pitt-Catsouphes, M., Kossek, E.E. and Sweet, S.A. (Eds.) (2006), The work and family handbook: Multidisciplinary perspectives, methods, and approaches, Lawrence Erlbaum Associates, Mahwah, N.J.

Powell, G.N. and Greenhaus, J.H. (2010), "Sex, Gender, and the Work-to-Family Interface: Exploring Negative and Positive Interdependencies", Academy of Management Journal, Vol. 53 No. 3, pp. 513-534.

Punnett, B.J. (1997), "Towards effective management of expatriate spouses", Journal of World Business, Vol. 32 No. 3, pp. 243-257.

Ruhm, C.J. (2004), How well do parents with young children combine work and family life?, NBER working paper series, Vol. 10247, National Bureau of Economic Research, Cambridge, MA.

Saxena, R. and Bhatnagar, D. (2009), "Gendered Career Patterns within Dual Career Couples", Vikalpa: The Journal for Decision Makers; , Vol. 34 No. 4, pp. 83-85.

Stephens, G.K. and Black, S. (1991), "The Impact of Spouse's Career-Orientation on Managers during International Transfers", Journal of Management Studies, Vol. 28 No. 4, pp. 417-428.

Stringer-Moore, D.M. (1981), "Impact of dual career couples on employers: Problems and solutions", Public Personnel Management, Vol. 10 No. 4, pp. 393-401. 
Suutari, V. and Tornikoski, C. (2001), "The challenge of expatriate compensation: the sources of satisfaction and dissatisfaction among expatriates", International Journal of Human Resource Management, Vol. 12 No. 3, pp. 389-404.

Thornton, R.L. and Thornton, M. (1995), "Personnel problems in "carry the flag" missions in foreign assignments", Business Horizons 1-2, pp. 59-66.

van der Zee, K.I., Ali, A.J. and Salome, E. (2005), "Role interference and subjective well-being among expatriate families", EUROPEAN JOURNAL OF WORK AND ORGANIZATIONAL PSYCHOLOGY, Vol. 14 No. 3, pp. 239-262.

Vermeulen, A. (2011), "The Hidden Costs of Globalisation", available at: http://www.expatprep.com/library/the-hidden-costs-of-globalisation/ (accessed 13 September 2014). 